Fixed Point Theory, 23(2022), No. 1, 21-34

DOI: $10.24193 /$ fpt-ro.2022.1.02

http://www.math.ubbcluj.ro/ nodeacj/sfptcj.html

\title{
COUPLED HILFER AND HADAMARD FRACTIONAL DIFFERENTIAL SYSTEMS IN GENERALIZED BANACH SPACES
}

\author{
SAÏD ABBAS*, MOUFFAK BENCHOHRA** AND ADRIAN PETRUŞEL*** \\ * Department of Electronics, \\ Tahar Moulay University of Saïda, P.O. Box 138, EN-Nasr, 20000 Saïda, Algeria \\ E-mail: said.abbas@univ-saida.dz, abbasmsaid@yahoo.fr \\ ** Laboratory of Mathematics, Djillali Liabes University of Sidi Bel-Abbès, \\ P.O. Box 89, Sidi Bel-Abbès 22000, Algeria \\ E-mail: benchohra@yahoo.com \\ *** Department of Mathematics, Babeş-Bolyai University, 400084 Cluj-Napoca, Romania \\ E-mail: petrusel@math.ubbcluj.ro
}

Abstract. This article deals with some existence and uniqueness of solutions for some coupled systems of Hilfer and Hilfer-Hadamard fractional differential equations. Some applications are made of generalizations of classical fixed point theorems on generalized Banach spaces.

Key Words and Phrases: Fractional differential equation, left-sided mixed Riemann-Liouville integral of fractional order, left-sided mixed Hadamard integral of fractional order, Hilfer fractional derivative, Hadamard fractional derivative, coupled system, generalized Banach space, fixed point.

2020 Mathematics Subject Classification: 26A33, 47H10, 54H25, 34A08.

\section{REFERENCES}

[1] S. Abbas, M. Benchohra, J.R. Graef, J. Henderson, Implicit Fractional Differential and Integral Equations: Existence and Stability, De Gruyter, Berlin, 2018.

[2] S. Abbas, M. Benchohra, J.E. Lazreg, Y.Zhou, A survey on Hadamard and Hilfer fractional differential equations: analysis and stability, Chaos, Solitons \& Fractals, 102(2017), 47-71.

[3] S. Abbas, M. Benchohra, G.M. N' Guérékata, Topics in Fractional Differential Equations, Springer, New York, 2012.

[4] S. Abbas, M. Benchohra, G.M. N'Guérékata, Advanced Fractional Differential and Integral Equations, Nova Science Publishers, New York, 2015.

[5] G. Allaire, S.M. Kaber, Numerical Linear Algebra, Texts in Applied Mathematics, Springer, New York, 2008.

[6] M. Benchohra, J. Henderson, S.K. Ntouyas, A. Ouahab, Existence results for functional differential equations of fractional order, J. Math. Anal. Appl., 338(2008), 1340-1350.

[7] K.M. Furati, M.D. Kassim, Non-existence of global solutions for a differential equation involving Hilfer fractional derivative, Electron. J. Differential Equations, 2013, no. 235, 10 pp.

[8] K. M. Furati, M.D. Kassim, N.E. Tatar, Existence and uniqueness for a problem involving Hilfer fractional derivative, Comput. Math. Appl., 64(2012), 1616-1626. 
[9] J.R. Graef, J. Henderson, A. Ouahab, Some Krasnosel'skii type random fixed point theorems, J. Nonlinear Funct. Anal., 2017 (2017), 1-34, Article ID 46.

[10] R. Hilfer, Applications of Fractional Calculus in Physics, World Scientific, Singapore, 2000.

[11] R. Kamocki, C. Obczńnski, On fractional Cauchy-type problems containing Hilfer's derivative, Electron. J. Qual. Theory Differ. Equ., 2016, no. 50, 1-12.

[12] A.A. Kilbas, Hadamard-type fractional calculus, J. Korean Math. Soc., 38(6)(2001), 1191-1204.

[13] A.A. Kilbas, H.M. Srivastava, J.J. Trujillo, Theory and Applications of Fractional Differential Equations, Elsevier Science B.V., Amsterdam, 2006.

[14] L. Liu, F. Guo, C. Wu, Y. Wu, Existence theorems of global solutions for nonlinear Volterra type integral equations in Banach spaces, J. Math. Anal. Appl., 309(2005), 638-649.

[15] H. Mönch, Boundary value problems for nonlinear ordinary differential equations of second order in Banach spaces, Nonlinear Anal., 4(1980), 985-999.

[16] D. O'Regan, R. Precup, Theorems of Leray-Schauder Type and Applications, Gordon and Breach, Amsterdam, 2001.

[17] M.D. Qassim, K.M. Furati, N.E. Tatar, On a differential equation involving Hilfer-Hadamard fractional derivative, Abstr. Appl. Anal., vol. 2012, Article ID 391062, 17 pages, 2012.

[18] M.D. Qassim, N.E. Tatar, Well-posedness and stability for a differential problem with HilferHadamard fractional derivative, Abstr. Appl. Anal., Volume 2013, Article ID 605029, 12 pages, 2013.

[19] I.R. Petre, A. Petruşel, Krasnoselskii's theorem in generalized Banach spaces and applications, Electron. J. Qualitative Theory Differ. Equ., (2012), no. 85, 20 pp.

[20] R. Precup, Methods in Nonlinear Integral Equations, Kluwer Academic Publishers, Dordrecht, 2002.

[21] S.G. Samko, A.A. Kilbas, O.I. Marichev, Fractional Integrals and Derivatives. Theory and Applications, Gordon and Breach, Amsterdam, 1987, Engl. Trans. from the Russian.

[22] M.L. Sinacer, J.J. Nieto, A. Ouahab, Random fixed point theorems in generalized Banach spaces and applications, Random Oper. Stoch. Equ., 24(2016), 93-112.

[23] V.E. Tarasov, Fractional Dynamics: Application of Fractional Calculus to Dynamics of Particles, Fields and Media, Springer, Heidelberg; Higher Education Press, Beijing, 2010.

[24] Ž. Tomovski, R. Hilfer, H.M. Srivastava, Fractional and operational calculus with generalized fractional derivative operators and Mittag-Leffler type functions, Integral Transform. Spec. Funct., 21(11)(2010), 797-814.

[25] R.S. Varga, Matrix Iterative Analysis, Springer Series in Computational Mathematics, 27, Springer-Verlag, Berlin, 2000.

[26] A. Viorel, Contributions to the Study of Nonlinear Evolution Equations, Ph.D. Thesis, BabeşBolyai University Cluj-Napoca, Department of Mathematics, 2011.

[27] J.-R. Wang, Y. Zhang, Nonlocal initial value problems for differential equations with Hilfer fractional derivative, Appl. Math. Comput., 266(2015), 850-859.

[28] Y. Zhou, J.-R. Wang, L. Zhang, Basic Theory of Fractional Differential Equations, World Scientific Publishing Co. Pte. Ltd., Hackensack, NJ, 2017.

Received: November 4, 2020; Accepted: June 14, 2021. 